\title{
Effects of Watermelon (Citrullus Lanatus) Seed on Blood Glucose and Electrolyte Parameters in Diabetic Wistar Rats
}

\author{
*10MIGIE IO; AGOREYO FO
}

\author{
Department of Physiology, School of Basic Medical Sciences, University of Benin, Benin City \\ Correspondence Address: Dr Mrs) Magdalene Omigie, Department of Physiology, School of Basic Medical Sciences, University of \\ Benin, Benin City, Email address: magdaleneomigie@yahoo.com
}

KEY WORDS: Watermelon, Diabetes, blood glucose, electrolyte, Wistar rats

\begin{abstract}
Given the prevalence of diabetes worldwide, with its associated complications, this study is aimed at investigating the effect of citrullus lanatus seed extract on blood glucose concentration and electrolyte parameters. Citrullus lanatus is an antioxidant and has been shown to reduce oxidative stress (Khaki et al., 2013). Effects of phytochemicals (flavonoids) on pancreatic $\beta$-cells leading to their proliferation and secretion of more insulin have been proposed by Mahesh and Menon (2004), as the mechanism by which medicinal plants used in the treatment of diabetes mellitus reduce hyperglycaemia in streptozotocin-induced diabetic rats. Fifteen female wistar rats were used in the study, they were divided into three groups of five rats each, namely; the control group, diabetes control group administered distilled water, and diabetes group administered watermelon seed extract. The diabetic groups were made diabetic by single intraperitoneal injection of streptozotocin $(60 \mathrm{mg} / \mathrm{kg})$. Daily watermelon seed extract was administered orally (200 mg per kilogram body weight), one week post streptozotocin injection. On 29th day the rats were sacrificed and blood was collected via the inferior vena cava, into plain bottles and fluoride oxalate sample tubes for electrolyte; $\left(\mathrm{Na}^{+}\right.$, $\mathrm{K}^{+}, \mathrm{HCO}_{3}{ }^{-}, \mathrm{Cl}^{-}$) and glucose analyses, respectively. Results showed that plasma glucose concentration decreased significantly $(\mathrm{P}<0.05)$ at week 2 and 4 . However, administration of methanolic extract of Citrullus lanatus seed did not have any significant effects $(\mathrm{P}>0.05)$ on $\mathrm{Na}^{+}, \mathrm{K}^{+}, \mathrm{Cl}^{-}$, and $\mathrm{HCO}_{3}{ }^{-}$concentrations . In conclusion, watermelon seed extract may be of supportive treatment to combat diabetes complications. (C) JASEM
\end{abstract}

\section{http://dx.doi.org/10.4314/jasem.v18 i2.12}

Despite the availability of medication for management of diabetes, the interest in alternative traditional remedies is increasing (Pari and Umamaheswari, 2000). Citrullus lanatus seed contains phytochemical constituents like alkaloids, flavanoids, tannins, amino acids, carbohydrates, cardioglycosides, terpenoids, oils and fats in the methanolic extract of plant material when compared with other solvents Flavanoids, have been reported to possess antiviral, anti-allergic, antiplatelet, antiinflammatory, antitumor and antioxidant activities (Johnson et al., 2012).

Antioxidants are compounds that protect cells against the da maging effects of reactive oxygen species, such as singlet oxygen, superoxide, peroxyl radicals, hydroxyl radicals and peroxynitrite (Johnson, 2001). Diabetes is one of the pathological processes known to be related to an unbalanced production of reactive oxygen species, such as hydroxyl radicals (HO), superoxide anions (O2) and hydrogen peroxide (H2O2). In diabetes there is decrease in the level of electrolytes $\left(\left(\mathrm{Na}^{+} \mathrm{Cl}^{-}\right)\right.$as a result of osmotic diuresis with subsequent loss of water and electrolytes induced by glycosuria (Adrogue et al., 1986).

\section{MATERIALS AND METHODS}

The following materials were used: Syringe and needle, Measuring cylinders Burette, volumetric flask, Beakers, conical flask, pipette, test tubes, Heparinized tubes, Plain tubes, electronic weigh balance, Cotton wool, Spectrophotometer, Stop watch, Dissecting set, Weigh machine, Centrifuge, Streptozotocin, Methanol, Chloroform.

Water melon fruit was obtained from New Benin, a local market in Benin City, Edo State. The flesh was removed and seeds collected were washed, sun-dried and milled into fine powder. This powdered sample was weighed into a beaker, soaked into $250 \mathrm{ml}$ of 
Methanol (absolute) stirring continuously for a period of 48 hours. At the end of 48 hours the solution was filtered and the filtrate was concentrated using a rotary evaporator, then freeze dried prior to usage. The administration of extract was totally by gavage.

Fifteen adult wistar albino female rats with an average weight of $190 \mathrm{~g}$ were used in this study. They were obtained from the animal house of the College of Medicine, Ambrose Alli University, Ekpoma, Edo State, Nigeria. The rats were allowed to acclimatize for a period of two weeks during which they were well fed with food and water. The rats were allocated into three groups, Group A: normal control $(n=5)$, Group B: diabetic control $(\mathrm{n}=5)$ and Group C: diabetes + watermelon seed extract $(n=5)$. The albino rats were fed growers mash once a day before the induction of diabetes and twice daily after inducing them with diabetes. The animals were maintained under laboratory conditions of room temperature, humidity and light. Diabetes was induced in rats by a single intraperitoneal injection of freshly prepared solution of $60 \mathrm{mg} / \mathrm{kg}$ body weight streptozotocin in physiological saline. Rats were monitored twice daily for body weight and for food and water intake.
Basal glucose levels for all the rats were determined prior to streptozotocin injection, using an automated blood glucose analyzer (Glucometer Elite XL). After one week of streptozotocin administration and $12 \mathrm{~h}$ of fasting, blood glucose was determined and rats with double blood glucose concentrations of the baseline were declared diabetic and used for the study. The seed extract of callinus decdyuu was administered to the rats for a period of 4 weeks.

On day 29 the rats were sacrificed and blood was collected by cardiac puncture into plain bottles and fluoride oxalate sample tubes for electrolyte; $\left(\mathrm{Na}^{+}\right)$, potassium $\left(\mathrm{K}^{+}\right)$, chloride $\left(\mathrm{Cl}^{-}\right)$, and bicarbonate ( $\mathrm{HCO}_{3}{ }^{-}$), and glucose analyses, respectively. The blood samples were taken to UBTH (University of Benin Teaching Hospital) to be analyzed. Glucose and electrolytes were assayed for using glucose oxidase method and flame photometry respectively.

Statistical Analysis

Datas are presented as means \pm S.E.M and analyzed by one way ANOVA according to the method of Snedecor and Cochran (1980). Groups were compared by the least significant difference test (LSD) at the 5\% level of probability. The data were analyzed by SPSS software.

\section{RESULTS AND DISCUSSION}

TABLE 1 Effect of watermelon seed extract administration on fasting blood glucose concentration (mg/dl)

\begin{tabular}{lccc}
\hline S/NO & $\begin{array}{c}\text { Group A } \\
\text { (Non-diabetic control } \\
\text { (normal) }) \mathrm{mg} / \mathrm{dl}\end{array}$ & $\begin{array}{c}\text { Group B } \\
\text { (Diabetic Control) } \\
\mathrm{mg} / \mathrm{dl}\end{array}$ & $\begin{array}{c}\text { Group C } \\
\text { (Diabetes + 200mg }\end{array}$ \\
\hline Baseline & $74 \pm 3.30$ & $70 \pm 1.58$ & $71 \pm 2.34$ \\
Induction & & $403.80 \pm 43.80$ & $419.75 \pm 33.45$ \\
Week 1 & $72.8 \pm 3.25$ & $204.2 \pm 40.05$ & $191.00 \pm 36.22$ \\
Week 2 & $73.4 \pm 2.42$ & $561.75 \pm 15.35$ & $369.67 \pm 79.77 *$ \\
Week 3 & $71.8 \pm 2.99$ & $481.33 \pm 71.93$ & $390.1 \pm 103.71$ \\
Week 4 & $76.0 \pm 2.32$ & $380.00 \pm 12.00$ & $266.75 \pm 99.54 *$ \\
\hline
\end{tabular}

Data presented as mean \pm SEM. *Values are significantly different $(\mathrm{P}<0.05)$ when compared with diabetic control.

TABLE 2 Effect of watermelon seed extract administration on serum electrolyte concentrations in diabetic rats.

\begin{tabular}{llll}
\hline PARAMETERS & $\begin{array}{l}\text { Group A } \\
\text { (Non-diabetic control } \\
\text { (normal)) }\end{array}$ & $\begin{array}{l}\text { GroupB (Diabetic } \\
\text { Control) }\end{array}$ & $\begin{array}{l}\text { Group C } \\
\text { (Diabetes+ 200mg } \\
\text { of watermelon seed extract) }\end{array}$ \\
\hline Sodium (meq/L) & $145 \pm 0.71$ & $148 \pm 0.00$ & $145 \pm 4.55$ \\
Potassium (meq/L) & $7.33 \pm 1.10$ & $6.15 \pm 0.65$ & $5.88 \pm 0.35$ \\
Bicarbonate (meq/L) & $15.50 \pm 1.44$ & $17 \pm 1.00$ & $15.25 \pm 1.32$ \\
Chloride (meq/L) & $119 \pm 0.58$ & $115 \pm 1.00$ & $117 \pm 1.29$ \\
\hline
\end{tabular}

Data presented as mean \pm SEM: The present investigation indicates that administration of the methanolic extract of Citrullus lanatus seed extract at a dose of $200 \mathrm{mg} / \mathrm{kg}$ body weight caused a reduction in the blood glucose concentrations in group C (diabetes + watermelon seed extract) at week
2 and 4 (Table 1). The presence of tannins and saponins, phytochemicals with recognizable hypoglycaemic effects, as well as the presence of soluble fibre and carbohydrates in citrullus lanatus seed, may contribute to this hypoglycaemic effect which is in line with the work done by (Nasiri et al., 
2009). Effect of phytochemicals (flavonoids) on pancreatic $\beta$-cells leading to their proliferation and secretion of more insulin have been proposed by Mahesh and Menon (2004) as the mechanism by which medicinal plants uses in reducing hyperglycaemia in streptozotocin-induced diabetic rats. Decrease in blood glucose concentration obtained from diabetes + extract group on the week 1 and 3, was not significant when compared to diabetic control group (Table 1). It is possible that this methanolic extract of Citrullus lanatus seed induces hypoglycemia by triggering insulin release from the $\beta$-cell of the islet of Langerhan or by hepatic glucose reduction, with the amount of insulin released directly related to the volume of extract administered. On the other hand, it is possible that this extract reduced blood glucose by stimulating insulin release from the $\beta$-cells of the pancreas that may have survived streptozotocin destruction (Onoagbe et al., 1999).

In diabetes there is decrease in the level of sodium ion as a result of osmotic diuresis with subsequent loss of water and electrolytes induced by glycosuria (Adrogue et al., 1986). Methanolic extract of Citrullus lanatus did not cause any significant difference in electrolyte concentration between the groups. This may be due to the duration at which the animals were diabetic, because electrolyte imbalance is not seen at the early stage of diabetes or it could be due to the concentration of administered dose.

In conclusion, watermelon seed extract may be of supportive treatment to combat diabetes complications as seen from the findings of this work.

\section{REFERENCE}

Adrogue, H.J, Ledere E.D , Suki W.N and Eknoyan G. (1986). Determination of plasma potassium levels in diabetic ketoacidiosis. Medicine. 65:163-172.
Johnson, J.T.,, Iwang, E.U., Hemen, J.z.. Odey,M.O., Efiong, E.E., Eteng, O.E. (2012). Evaluation of anti-nutrient contents of watermelon Citrullus lanatus. Ann Biol Res. 3(11):5145-5150.

Johnson, I.T., Pokorny, J. N., Gordon, M. (2001). Antioxidants and Antitumour Properties. In: Antioxidants in Food, (Eds.). p 100-123.

Khaki, A, Fatemeh F and ohammedN.(2013).Effects of water melon seed extract (Citrullus Vulgaris) on spermatogenesis in rat. Int. J. women's health reproduction sci. 1:3.

Mahesh T and Menon VP. (2004). Quercetin lleviates oxidative stress in streptozotocin- induced diabetic rats. Phytother Res. 18: 123-127.

Nassiri, M., Khaki, A., Gharachurlu, S., Ashteani, A.

Rastegarnea, K., Rezazadeh, S. (2009). Effects of Ginger on spermatogenesis in Streptozotocin induced Diabetic Rat, Iran. J. Med. Plants, 8(31):118-125.

Onoagbe, I.O., Lau, H.U., Esekheigbe, A., Dawha, I.M., Salami, C.O. (1999). Effects of Irvingia grandifolia and Spondias mombin on blood glucose and triglyceride concentrations in streptozotocin-induced diabetic rats. Biokemistri, 9(1): 17-22.

Pari, L., Umamaheswari, J. (2000). Antihyperglycaemic activity of Musa sapientum flowers: effect on lipid peroxidation in alloxan diabetic rats. Phytother. Res., 14: 1-3. 